\title{
BMJ Open Advancing a health equity agenda across multiple policy domains: a qualitative policy analysis of social, trade and welfare policy
}

\author{
Belinda Townsend (D) , ${ }^{1}$ Sharon Friel, ${ }^{1}$ Toby Freeman, ${ }^{2}$ Ashley Schram, ${ }^{1}$ \\ Lyndall Strazdins, ${ }^{3}$ Ronald Labonte, ${ }^{4}$ Tamara Mackean, ${ }^{5}$ Fran Baum ${ }^{2}$
}

To cite: Townsend B, Friel S Freeman T, et al. Advancing a health equity agenda across multiple policy domains: a qualitative policy analysis of social, trade and welfare policy. BMJ Open 2020;10:e040180. doi:10.1136/ bmjopen-2020-040180

- Prepublication history and additional material for this paper are available online. To view these files, please visit the journal online (http://dx.doi. org/10.1136/bmjopen-2020040180).

Received 07 May 2020 Revised 16 0ctober 2020 Accepted 20 0ctober 2020

Check for updates

(c) Author(s) (or their employer(s)) 2020. Re-use permitted under CC BY-NC. No commercial re-use. See rights and permissions. Published by BMJ.

For numbered affiliations see end of article.

Correspondence to Dr Belinda Townsend; belinda.townsend@anu.edu.au

\section{ABSTRACT}

Objective While there is urgent need for policymaking that prioritises health equity, successful strategies for advancing such an agenda across multiple policy sectors are not well known. This study aims to address this gap by identifying successful strategies to advance a health equity agenda across multiple policy domains.

Design We conducted in-depth qualitative case studies in three important social determinants of health equity in Australia: employment and social policy (Paid Parental Leave); macroeconomics and trade policy (the Trans Pacific Partnership agreement); and welfare reform (the Northern Territory Emergency Response). The analysis triangulated multiple data sources included 71 semistructured interviews, document analysis and drew on political science theories related to interests, ideas and institutions.

Results Within and across case studies we observed three key strategies used by policy actors to advance a health equity agenda, with differing levels of success. The first was the use of multiple policy frames to appeal to a wide range of actors beyond health. The second was the formation of broad coalitions beyond the health sector, in particular networking with non-traditional policy allies. The third was the use of strategic forum shopping by policy actors to move the debate into more popular policy forums that were not health focused.

Conclusions This analysis provides nuanced strategies for agenda-setting for health equity and points to the need for multiple persuasive issue frames, coalitions with unusual bedfellows, and shopping around for supportive institutions outside the traditional health domain. Use of these nuanced strategies could generate greater ideational, actor and institutional support for prioritising health equity and thus could lead to improved health outcomes.

\section{INTRODUCTION}

Research and policy discussions on the social determinants of health $(\mathrm{SDH})$ and health inequities have increased in the recent decade, featuring in several high-level international policies ${ }^{1-4}$ and peer-reviewed analyses including in The Lancet. ${ }^{5-7}$ Health researchers have shown unequivocally that
Strengths and limitations of this study

- Three in-depth qualitative case studies were conducted in social, trade and welfare policy.

- Purposive and snowball sampling was used to capture a range of policy actor views.

- As in depth case studies the findings are not generalisable but can be interrogated through further research in other policy settings.

social conditions, such as healthcare, education, the conditions of work, home, communities and our environments, affect people's health and its social distribution. ${ }^{8-10}$ Despite this, readily preventable health inequities persist across different social stratifiers including income, gender, education and race. For example, in 2020 in England, life expectancy is decreasing for women in the most deprived areas. ${ }^{11}$ In more than 23 Organisation for Economic Co-operation and Development countries, mortality rates are almost four times higher for men aged 25-64 with less education compared with those with tertiary education. ${ }^{12}$ In Australia, despite improvements, Aboriginal and Torres Strait Islander life expectancy remains around 8 years less compared with non-Indigenous Australians. ${ }^{13}$

The evidence is clear on the need for equity focused policies within and beyond the health sector. ${ }^{14-17}$ Equity-focused policies refers to efforts to reduce systematic inequities in health that arise from unequal access to health resources or to practices of social exclusion (eg, racism and discrimination) that are preventable and considered to be unjust. ${ }^{18}$ Policy research has identified a number of factors that can constrain government attention to the SDH equity (SDHE), including; limited supporting evidence; perceived complexity of the problem; frames 
and ideologies opposed to a SDHE approach; path dependency; and the dominance of a biomedical paradigm and medical profession. ${ }^{19-31}$ Favourable conditions identified in a recent narrative review of 48 articles $^{20}$ include; new data and evidence; support for SDHE frames; civil society mobilisation; strong champions or leaders; alignment with the ideology of the government of the day; and supportive health institutions. Less is known about the conditions which can drive agendasetting for health equity in those policy sectors beyond healthcare and health systems that indirectly impact health. In this regard, scholars point to health actors' unfamiliarity of the social, political and economic environments that shape non-health sectors' policymaking. ${ }^{21}$ We investigated this knowledge gap through three in-depth qualitative case studies of policymaking which originated outside the health sector and which had an impact on health equity outcomes. The aim was to identify successful strategies to advance a health equity agenda across multiple policy domains.

The paper adopts a policy studies approach that recognises that policymaking is not a linear process, but the result of a contest of interests and ideas within institutional structures. We draw on institutional theory which positions interests, ideas and institutions as variables in understanding policy change, ${ }^{32}$ and a framework of conditions found to generate political priority in global health. ${ }^{33}$ The focus of this approach is on the interplay between ideational and material factors, where framing is 'central to explaining how consensus is built around certain policy choices'. ${ }^{34}$

\section{METHODS}

We selected retrospective case studies in Australian public policy that represent powerful SDHE: employment and social policy (Paid Parental Leave (PPL)); macroeconomics and trade policy (the Trans Pacific Partnership (TPP) Agreement) and welfare reform (Northern Territory Emergency Response (NTER)). We selected Australia's adoption of a national PPL scheme because of its significance as a major national social policy initiative in Australia that explicitly included promoting heath as a core goal. ${ }^{35}$ The TPP was selected because it exemplifies a new generation of preferential trade agreements with a wide agenda and potential impacts for public health. ${ }^{36}$ Australia negotiated this mega-regional trade agreement with other countries in the Pacific Rim. The NTER was selected as an example of welfare reform and public policy that had significant impacts on Indigenous health. There is no published literature using an equity focus to examine how the development of this policy was likely to affect the health of Aboriginal peoples. None of these policies originated within the remit of the Department of Health portfolio, although each case had different degrees of attention to health and some of them evolved to incorporate health equity concerns (see box 1 ).

\section{Box 1 Policy cases}

Employment and social policy case: Paid Parental Leave (PPL)

- In 2009, the Australian government legislated its first national PPL scheme, which provides 18 weeks' pay at the minimum wage for primary caregivers on the birth of a child. Australia was one of the last high-income countries to introduce a PPL scheme, which subsequently demonstrated improvements for health equity. This major intersectoral social policy crosses industrial relations and employment, gender equality and family health, and was led by the Federal Department of Social Services.

Macroeconomics and trade case: Trans Pacific Partnership (TPP) agreement

- The TPP agreement was a mega-regional trade and investment agreement negotiated between Australia and fifteen other Pacific Rim countries. The USA led the negotiations but withdrew in 2017. Analysis of the final text of the agreement raised public health concerns for potential impacts on employment and labour conditions, the liberalisation of health harmful commodities, and constraints on government regulatory space. Access to medicines and tobacco control appeared to receive some attention in Australia. The TPP was led by Australia's Federal Department of Foreign Affairs and Trade.

\section{Welfare reform: The Northern Territory Emergency Response (NTER)}

- The NTER was a racially focused suite of social and welfare reform measures and military intervention into Aboriginal communities in the Northern Territory of Australia introduced in 2007. The NTER was framed as response to the problem of child sexual abuse but was found to negatively affect Aboriginal people's health through a diminished sense of personal control and political self-determination. The NTER was led by the Federal Department of Families, Housing, Community Services and Indigenous Affairs.

\section{Data collection}

The findings presented in this paper are based on analyses of the three in-depth qualitative case studies. The methods included document analyses and key informant interviews, details of which for each of the three case studies are provided later.

Data included semistructured interviews with key stakeholders intimately involved in agenda-setting in the three case studies, analysis of government and non-government reports, policy actors' submissions to government, media reporting, parliamentary transcripts, and peerreviewed and grey literature (see table 1 for document information).

To guide the interviews, we drew on theoretical concepts from the policy science literature. This included institutional theory which position interests, ideas, and institutions as variables in understanding policy change, and identifying framework conditions that generating political priority for health. ${ }^{32}{ }^{33}$ In institutional theory 'interests' refer to the 'agendas of societal groups, elected officials, civil servants, researchers, and policy entrepreneurs' ${ }^{37}$ 'Ideas' refer to how policy actors understand or frame an issue, shaped by their values, beliefs and ideologies. ${ }^{32-38}$ Institutions are defined as the formal and informal rules 
Table 1 Documents

\begin{tabular}{|c|c|c|c|}
\hline & PPL & NTER & TPP \\
\hline Documents & $\begin{array}{l}\text { Prior to interviews, documents } \\
\text { were sourced from archived } \\
\text { searches of Parliamentary Hansard } \\
\text { (government bills, parliamentary } \\
\text { debates) and Factiva (Australian } \\
\text { media reporting) using key terms } \\
\text { 'maternity leave' and 'parental } \\
\text { leave'. Key government reports and } \\
\text { submissions to government inquiries } \\
\text { between } 2000 \text { and } 2009 \text { were also } \\
\text { collected. Academic databases } \\
\text { (Web of Science) were also searched } \\
\text { using terms 'parental leave' and } \\
\text { 'welfare state' to identify key texts } \\
\text { on Australia's welfare state history } \\
\text { and PPL in industrial relations and } \\
\text { economics. These documents were } \\
\text { read to identify potential informants, } \\
\text { construct a timeline of chronological } \\
\text { events, and cross reference facts and } \\
\text { give further depth and context to the } \\
\text { interview data. }\end{array}$ & $\begin{array}{l}\text { Prior to interviews, we searched } \\
\text { Trove, Factiva, Hansard, Google } \\
\text { and government websites (including } \\
\text { pages for previous members } \\
\text { of parliament) using the terms: } \\
\text { 'Little Children Are Sacred report', } \\
\text { 'Northern Territory Emergency } \\
\text { Response', 'A proposed Emergency } \\
\text { Response and Development Plan', } \\
\text { 'Combined Aboriginal Organisations } \\
\text { of the Northern Territory'. We } \\
\text { searched for speeches, media } \\
\text { releases or media interviews/quotes } \\
\text { from key actors during the policy } \\
\text { agenda setting period (15 June-17 } \\
\text { August } 2007 \text { ). The Little Children Are } \\
\text { Sacred report and Alternative plan } \\
\text { were also included as data as key } \\
\text { policy agenda setting documents. } \\
\text { We found a total of } 72 \text { sources that } \\
\text { were included documents. }\end{array}$ & $\begin{array}{l}\text { Prior to interviews, we used a } \\
\text { theory-guided process tracing } \\
\text { method to create a timeline of } \\
\text { key events during Australia's } \\
\text { participation in the TPP negotiations. } \\
\text { Publicly available submissions made } \\
\text { by non-government organisations } \\
\text { to the Australian government } \\
\text { (ie, policy-oriented documents } \\
\text { expressing their position on the } \\
\text { negotiations and what did or did } \\
\text { not want the government to agree } \\
\text { to) were downloaded from the } \\
\text { government website ( } \mathrm{n}=87 \text { ), were } \\
\text { read and thematically coded using } \\
\text { framing analysis and network } \\
\text { analysis methods (published } \\
\text { elsewhere). These analyses informed } \\
\text { the semi-structured interview } \\
\text { schedule. Interview questions were } \\
\text { pilot-tested with two experts in } \\
\text { trade and investment policy before } \\
\text { commencing. }\end{array}$ \\
\hline
\end{tabular}

NTER, Northern Territory Emergency Response; PPL, Paid Parental Leave; TPP, Trans Pacific Partnership.

of the game and the "norms, precedents and organisational factors that structure political behaviour'. ${ }^{34}$ Institutions such as government structures and policy legacies shape policymaking in ways that favour some interests or ideas over others (see the interview guides in online supplemental file).

Seventy-one semistructured interviews were conducted with individuals intimately involved in the agenda-setting stage of the policies (see table 2). Most informants were from outside the health policy sector. Informants were recruited using purposive and snowball sampling through

\begin{tabular}{lccc}
\hline Table 2 Interview informants & & & \\
\hline & PPL & TPP & NTER \\
\hline $\begin{array}{l}\text { Politicians or their political } \\
\text { advisors }\end{array}$ & 5 & 5 & 5 \\
$\begin{array}{l}\text { Public servants } \\
\text { Industry }\end{array}$ & 8 & 5 & 6 \\
Trade union & 4 & 5 & 0 \\
Civil society & 2 & 1 & 0 \\
Academic expert & 4 & 4 & 3 \\
Aboriginal community-controlled & 0 & 0 & 5 \\
organisation & 2 & 5 & 1 \\
Journalist & 0 & 0 & 1 \\
Total & 25 & 25 & 21 \\
\hline
\end{tabular}

NTER, Northern Territory Emergency Response; PPL, Paid Parental Leave; TPP, Trans Pacific Partnership. consulting published documents and grey literature and by asking informants who they considered key actors in each of the policy cases. This method helped us to reach saturation, where major concepts had been identified and additional interviews were judged unlikely to reveal new information. Interviews were conducted in English and were in-person or over the phone for approximately $45 \mathrm{~min}$. Interviews were conducted between August 2016 and November 2017 (PPL), November 2017 and July 2018 (TPP), and October 2018 and November 2019 (NTER). The notes and transcripts of the recordings and audio files were de-identified and secured to ensure confidentiality. Prior to coding and analysis, interviews were transcribed verbatim and imported into QSR NVivo11 (QSR International).

Data were analysed using a combination of deductive and inductive thematic analysis. ${ }^{39}$ A deductive coding schema was initially developed by the author team informed by our core theoretical concepts (eg, actors and their interests; ideas, and framings; formal and informal institutions; and political context) (see table 3), with new themes developed iteratively as four analysts read the transcripts. Two researchers coded a set of documents in each case to develop an initial coding framework, which was then discussed with the wider team. The coding framework was then refined and findings discussed in four analysis workshops (one for each case and one for cross-case). Analysing informant accounts thematically allowed for identification of core factors and conditions, with cross-case common themes identified in discussions 
Table 3 Ideas, interests and institutions at play in the three policy cases

PPL (economic and social policy)

Ideas (frames)

Interests (actors and coalitions)

Neoliberalism, sexism, economic productivity, 'the business case', gender equality, maternal and child health, population growth

Women's organisations, trade unions, public servants, politicians, academic experts, industry groups, socially conservative organisations, social justice groups, public health and women's health organisations

$\begin{array}{ll}\text { Institutions (policy legacies, } & \text { Policy legacy: Australia's } \\ \text { norms and rules) } & \text { 'wage-earner' welfare state } \\ \text { Incentives and rules in the } \\ \text { industrial relations policy } \\ \text { settings } \\ \text { Alternative incentives and } \\ \text { rules in the Human Rights } \\ \text { and Equal Opportunity } \\ \text { Commission and Productivity } \\ \text { Commission }\end{array}$

NTER, Northern Territory Emergency Response; PPL, Paid Parental Leave; TPP, Trans Pacific Partnership.
Policy legacy: rules for consultation and engagement in the Department of Foreign Affairs and Trade Policy legacy: norms for publicly funded healthcare in Medicare
NTER (social and welfare reform)

Neoliberalism, economic growth, investor rights, public interest, state sovereignty, Racism, social conservatism, whiteness, Aboriginal selfdetermination, land rights access to medicines

Public servants, politicians, industry groups, civil society organisations, public health networks, academic experts

Public servants, politicians, Aboriginal community-controlled organisations, medical associations, civil society groups among research team members. Interview findings were triangulated with the analysis of documents to verify and check information.

The thematic analysis presented in this paper is drawn from findings from the three case studies and was led by the lead author in consultation with the coauthors, several of whom were involved in the original case study research and analyses. This post-hoc analysis uses political science theories related to interests, ideas and institutions to examine similarities and differences across the three cases to explore how health equity enters into policy agenda-setting in non-health policy sectors.

\section{Patient and public involvement}

No patient involvement.

\section{RESULTS}

In each of these cases, the majority of policy actors worked outside of the health sector, with different objectives and goals to a public health agenda. Through the policy agenda-setting processes, some of the actors began to focus on health as part of their broader social policy agenda, and in other instances health actors were able to drive attention towards health equity. The PPL case demonstrated the greatest success, with health and gender equity emerging as key policy goals. In contrast, health remained a marginal concern in the trade case, although two health issues received some attention on the domestic agenda. In the case of the NTER, health was a driving rationale but health equity did not get onto the government's agenda. In all cases, a range of frames were used by different groups of actors, with policy legacies serving as particular constraints that needed to be navigated (see table 3 ).

Three key strategies appeared to contribute to greater success for generating attention to health equity (and less success in their absence). The first strategy was the use of multiple synergistic frames to appeal to a wider range of actors and institutions. The second was the formation of broad coalitions beyond the health sector to include non-traditional policy allies to drive change. The third was strategic forum shopping between policy venues, with the aim of breaking open constraining frames and shifting the agenda-setting into more favourable (and not necessarily health-focused) policy forums. Each of these findings is explained in more detail below.

\section{Using multiple synergistic frames}

How policy issues were framed was crucial to the success or neglect of health equity in our three cases. Through the analysis we found that actors used multiple frames to contest and shift the dominant constraining policy framing, and, crucially, that health and equity frames were not always the most pragmatic frame to drive an equity agenda forward.

Across the policy domains, the dominance of a neoliberal economic framing was seen as particularly constraining. Neoliberalism generally is seen as 'referring 
to the new political, economic and social arrangements within society that emphasize market relations [and] re-tasking the role of the state', extending a discourse of 'competitive markets into all areas of life ${ }^{40}$ In the case of PPL, this framing lent discursive power to industry groups who opposed paying for maternity or parental leave, viewing it as a private, individual and non-market responsibility. ${ }^{41}$ In the case of trade, government and industry groups shared a common language promoting export growth and market liberalisation which pushed public interest arguments by civil society and public health actors onto the periphery. ${ }^{42}$ In the NTER, punitive and controlling social and welfare measures were justified using neoliberal economic arguments of the benefit of directing certain behaviours in the marketplace, regardless of unfair or racist outcomes for Aboriginal people including loss of autonomy. Other constraining framings we identified included sexist framing of women's role as principally home-based caregivers (PPL), and racist and paternalistic deficit framing of Aboriginal people (NTER) (see table 3). These frames were upheld by the dominant neoliberal paradigm; neoliberal policies that sought to reduce the welfare state relied on women's unpaid work at home, increasing class inequities. In turn, sexist framings relied on and promoted gendered views about family and work and were used to resist pro-feminist policy changes. ${ }^{43}$ In the case of the NTER, racist and paternalist deficit framing of Aboriginal people was used to justify neoliberal welfare reform.

The analysis identified a key strategy used by actors to contest and shift the dominant policy framing. This strategy involved the use of multiple frames, and was most successful in the PPL case. In response to industry opposition and government inaction on the issue of paid maternity and parental leave, advocates for PPL from the public service, academia, trade unions, women's groups and politicians began developing multiple frames including economic, gender equality, and maternal and child health frames. By positioning paid maternity and parental leave as important for economic productivity, for gender equality in the workplace, for employers' 'business case' for retaining women in the workforce, and for improving maternal and child health, this informal coalition of actors exercised discursive power that helped rupture decades of opposition to PPL in Australia. ${ }^{41}$ Importantly, public servants, trade union representatives, academic experts, representatives from women's organisations and other civil society organisations and politicians we interviewed emphasised the importance of using many framings other than equity or health to appeal to a wider range of interests and values. Analysis of the interview data revealed that gender equity advocates in the public service, women's organisations and trade unions took up the health framing as a pragmatic decision to buttress opposing arguments and convince politicians of the importance of a PPL scheme. ${ }^{41}$ Crucially, many informants also reported that, while equity was an underlying rationale, it was not seen as the winning argument, and other frames such as economic productivity and gender equality were used to drive forward a pro-PPL agenda. It was not that health or equity were considered unimportant but that a wider set of frames needed to be used simultaneously in different forums to build momentum for change.

This multiple framing strategy appeared to a lesser degree in the trade case, where public interest advocates used counter frames to advance state sovereignty and promote the public interest but were ultimately unable to shift debate outside of the dominant neoliberal paradigm. Public-interest informants we spoke to representing trade unions, civil society, public health organisations, and politicians, public servants and academic experts spoke of their attempts to counter-frame the TPP agreement as an issue of protecting the public interest and public health. Many of these informants noted that where there was some attention to health issues (eg, domestic concerns for access to medicines), this could in part be explained because these interests aligned well with neoliberal framing for promoting greater access to goods in the market. ${ }^{44}$ In contrast, in the NTER case, Aboriginal organisations, some politicians, academic experts, public servants and other civil society bodies we interviewed spoke of their attempts to advance Aboriginal health equity and self-determination using a social determinants framing. Such a framing included the impacts of racism and trauma and the importance of rights and justice for health. Ultimately these advocates reflected that they could not overcome the dominant whiteness (ie, the idea of colonial peoples as superior to First Nations peoples) and deficit framing of Aboriginal peoples as perpetrators, victims and sub-humans within government and mainstream media.

\section{Forming broad coalitions with non-traditional policy allies}

A second key challenge to advancing a health equity agenda as identified by informants in each of the cases was the myriad of actors seeking to shape the policy agenda, a majority of whom were not health-oriented. Through the analysis, we identified a second important strategy which was the formation of broader coalitions with nontraditional policy allies to advance a health equity agenda outside the health policy domain.

Across the policy cases, the economic power of industry groups who opposed to, policies that would act on social determinants but which could affect their material interests was particularly constraining. For example, industry employer groups opposed paying for maternity leave in Australia, with some threatening not to hire women if they were required to pay. ${ }^{41}$ In the case of trade, former government officials reported that the purpose of trade agreements was principally 'for Australian industry" with health a tangential concern at best. In the case of the NTER, a majority of informants saw the Federal Government's structural power over Aboriginal communities constraining any potential for a more inclusive and consultative heath equity agenda. 
However, to overcome this powerful opposition, a number of public-interest interviewees identified efforts to form broad coalitions beyond the health sector with non-traditional policy allies. The PPL case demonstrated the most success using this strategy, with policy advocates highlighting the importance of widening their informal coalition to include not just supportive public servants, women's organisations, trade unions, peak civil society bodies and academic experts but, crucially, supportive industry actors. To do this, informants from women's groups, the public service, trade unions, academia and other civil society bodies focused on developing a 'business case' framing for a government funded PPL scheme as part of their arsenal of policy frames, as well as a gender equality frame emphasising the benefits of improving women's employment. ${ }^{41}$ This coalition-building was ultimately successful in gaining support from a range of industry groups, which then gave economic legitimacy to the case for a PPL scheme. Interestingly, we found little engagement from government health officials in the agenda-setting in the PPL case, which was surprising given the potential health equity benefits of the policy.

Generating support from a wide range of actors was also evident in the trade case. Public interest informants reflected on the formation of a civil society and public health network comprised academics, trade unions and community and health groups which focused on the TPP negotiations. Unlike the PPL case, however, this network did not seek to build a wider coalition with powerful economic actors, whose trade position was almost diametrically different, leaving little possibility to disrupt entrenched trade/health power dynamics. Several informants noted that where there was some success for the issues of access to medicines and tobacco control there was a broad range of supportive actors including the Productivity Commission (an independent government body for economic analysis), the Department of Health and the generic medicines industry.

In the case of the NTER, a close coalition of Aboriginal community-controlled organisations opposed the NTER social and welfare reforms and advocated a selfdetermination approach, but were unable to overcome the structural power of the Federal Government which had introduced the legislation. Also apparent were underlying tensions between some Aboriginal led and non-Indigenous organisations, with one informant lamenting that some non-Indigenous organisations were not strong allies and were instead positioning themselves for resources from the NTER policy. Nonetheless, several informants noted that one of the most controversial measures proposed, a compulsory physical health check on all Aboriginal children in the Northern Territory for signs of sexual abuse, was defeated and removed from proposed government legislation. Credit for this was ascribed to its opposition from a wide group of actors that included Aboriginal led organisations, supported by officials within the Department of Health and a powerful medical lobby from the Australian Medical Association.

\section{Forum shopping}

A third key barrier to advancing a health equity agenda was the constraining effect of institutions such as government structures and policy legacies, many of which were designed to serve interests and objectives other than health and health equity. An important strategy we identified was the use of strategic forum shopping by advocates to shift policy debate away from constraining institutions and towards more supportive and open forums. Forum shopping is defined in political economy literature as actors selecting venues 'based on where they are best able to promote specific policy preferences' ${ }^{45}$ and working strategically to shift policy discussion to those forums.

In the case of PPL, several informants reflected on the path dependency of Australia's wage-earner welfare state system as a particularly constraining policy legacy that excluded women's voices. ${ }^{46}$ Furthermore, the rules of the game within the industrial relations setting narrowly focused on economics and enabled powerful employer associations to simply refuse to pay for maternity leave. ${ }^{41}$ In the case of trade, public health and civil society informants were highly critical of the Department of Foreign Affairs and Trade rules for consultation, which they saw as producing a lack of meaningful engagement and a lack of transparency. ${ }^{44}$ In the case of the NTER, many informants situated the policy within a longer history of colonisation and dispossession which has excluded Aboriginal people and Aboriginal controlled organisations from crafting policies that affect their lives.

The strategy used by actors to try to overcome these institutional challenges was that of strategic forum shopping. This strategy involved attempts to shift the issue away from policy forums with constraining policy legacies and into those forums with more favourable incentives and rules for driving an agenda favourable to health equity. Again, this strategy was particularly successful in the PPL case. Drawing on a range of frames, several informants from the public service, academia and women's organisations described their efforts to establish an inquiry on PPL in the independent Human Rights and Equal Opportunity Commission, a forum which had very different incentives and procedural rules from industrial relations, as a way to break open the discourse to include gender equality and health as legitimate frames. ${ }^{41} \mathrm{~A}$ few years later, this grouping worked to secure commitment for an inquiry within the Productivity Commission, an independent economic policy arm of government with different rules and incentives, this time in order to secure economic support and legitimacy for a PPL scheme. These forumshopping manoeuvres appeared to be crucial, with the newly elected Federal Government accepting the recommendations for a government-funded PPL scheme. ${ }^{41}$

In contrast, there were fewer alternative forums to advance a health equity agenda in the other policy cases. In the trade case, many informants saw the Department of Foreign Affairs and Trade as exercising significant power through its remit as the negotiating representative for Australia, and many were highly critical of a lack 
of meaningful engagement. Civil society informants we spoke to recounted efforts to break open the rules and norms within this trade forum to enable greater engagement on the SDH. ${ }^{44}$ This included lobbying parliamentarians to establish Committee inquiries and other forums to raise health and social concerns. ${ }^{47}$ Inside government, some health officials were also critical of what they perceived as trade officials controlling the scope of issues and terms of consultations with the Department of Health. Interestingly, where there was some domestic attention to health in the context of the negotiations (eg, access to medicines), one trade informant reflected on the entrenched policy legacy in Australia for publicly subsided medicine as an embedded institution that they were very cognisant of in the negotiations.

Institutional barriers were also powerful constraints in the NTER case, where the Federal Government shifted the policy forum away from a subnational Northern Territory forum widely supported by informants to be promoting an equity agenda, to one that they could control as a top-down, Federal Government intervention into the Northern Territory with increased policing, surveillance, and welfare reform. In doing so, this stifled opportunities for Aboriginal community-controlled organisations and health officials to advance an equity agenda. Government health official interviewees reported feeling being locked out of the process. As one informant reflected, there was a 'war room' set-up in the Federal Government for the NTER policy, and health officials were given responsibility over a select and small number of medical and health service tasks. Health officials reported using what power they had to support funding flowing to Aboriginal primary healthcare and to oppose the most punitive measures of the NTER. Overall, however, colonising institutional power dynamics inside and outside of government constrained a health equity agenda.

\section{DISCUSSION}

How to get governments to prioritise policies for health equity remains a difficult challenge because it requires leadership and engagement across multiple policy sectors. Much of the existing literature has focused on necessary conditions in the health sector, such as the importance of supportive health institutions, generating new health evidence and strong health leaders and policy champions in government. ${ }^{15-31}$ This analysis adds to the existing literature by identifying nuanced strategies particularly for strategic framings and coalitions with unusual bedfellows, and suggests a forum shopping strategy that appears unique for agenda-setting across multiple sectors.

First, while framing has been shown to be an important ideational strategy in global and public health debate, ${ }^{19-22}$ our findings point to the need to develop multiple policy framings to drive a health equity agenda across many sectors, where advocates must be able to layer frames and use different frames strategically at different times. The PPL case, for example, showed that four contrasting frames-good for business, gender equality, economic productivity and equity - were developed over time. Policy actors seeking to drive attention to an equity agenda will likely need to assess the benefits of using other frames such as economic, gender or human rights frames, where appropriate. This ability to articulate other arguments or the ability to activate experts who can (eg, economists, human rights, gender equity, race relations experts and groups) underscores the essential interdisciplinary skill set required for any policy advocate seeking to address the social and economic forces that shape health inequities.

Second, our analysis adds to the well-known literature on the importance of advocacy coalitions by demonstrating the contributions of broad coalitions of nontraditional public health allies in driving a heath equity agenda forward. Crucially, we found that engagement by government health officials did not appear to be a key requirement for driving forward multisectoral policies that would improve health equity. This illustrates the potential for other portfolios to drive a health equity agenda, although with different framings and coalitions than traditionally used in public health. The formation of wider coalitions of non-traditional allies such as industry actors, government economic bodies, trade unions and non-health public servants-indeed unusual bedfellows-appeared crucial to garner support for policymaking across multiple sectors.

Third, our findings around the strategic use of forumshopping as a strategy to garner support appears more important and unique for agenda-setting across multiple sectors. This suggests that in policy areas that affect people's health but where policymakers do not see health as their remit, the ability to shift issues into more supportive forums appears necessary. Again, these forums are likely not going to be health-specific, and the development of a range of frames (ie, gender equity, economic development) is needed to shift policy discussion into new forums which can advance policies for health equity without relying solely on a health frame or a health policy champion.

The analysis also points to the limitations and challenges for policy advocates when there is entrenched structural power and discrimination in a policy domain. We found that in the case of trade (TPP) the dominant neoliberal framing was so pervasive in government and mainstream media that public interest and public health advocates had limited success in shifting the framing to encompass SDH. The institutional processes for consultation were limited in the view of many of our informants, with the Department of Foreign Affairs and Trade seen as exercising significant power through its remit as the negotiating representative for Australia and by controlling the terms of engagement. The case points to the need for reform in the government's treaty making process to enable greater transparency and intersectoral consultations, as has been called for by independent government inquiries. In the case of the NTER, policy advocates for an SDH approach could not overcome the dominant 
whiteness and deficit framing of Aboriginal peoples as perpetrators, victims and subhuman within government and mainstream media. Colonising institutional power dynamics inside and outside of government constrained Aboriginal organisations, and the structural power of the Federal Government to suspend the Racial Discrimination Act and intervene in the Northern Territory was entrenched. The case points to the need for structural reform to institutionalise Aboriginal participation in governance and decision-making processes, including Voices in Parliament, and for ideological reform through processes such Truth Telling and Treaty Making, to transform entrenched structural violence and power asymmetries.

Overall, these findings have implications beyond our specific policy case domains. As we noted in our introduction, much of the SDH equity are shaped by policymaking in sectors like taxation policy, finance and investment policy, education and housing policy, not to mention multisectoral policies requiring whole of government effort. The use of strategic frames, non-traditional allies, and a wider range of forums are three key strategies that could advance prioritisation for policies that improve health equity. Institutional reforms to enable greater participation in policy processes would also counter entrenched power imbalances that have historically prevented multi-sectoral policy for health.

\section{Limitations of the study}

This study was based on three qualitative in-depth case studies in Australian public policy. While some common patterns emerged across the case studies concerning health-equity agenda-setting (or its absence), exploration of further sectors would support greater generalisability. We were able to track temporal changes in framing strategies in the PPL case which had a longer time period of policy agenda-setting and development compared with the TPP and NTER cases which were more challenging to map framing shifts over the shorter time periods.

\section{Author affiliations}

${ }^{1}$ Menzies Centre for Health Governance, School of Regulation and Global Governance, Australian National University, Canberra, Australian Capital Territory, Australia

${ }^{2}$ Southgate Institute of Health, Society and Equity, Flinders University, Adelaide, South Australia, Australia

${ }^{3}$ National Centre for Epidemiology and Research School of Population Health, Australian National University, Canberra, Australian Capital Territory, Australia ${ }^{4}$ School of Epidemiology and Public Health, University of Ottawa, Ottawa, Ontario, Canada

${ }^{5}$ Aboriginal and Torres Strait Islander Health, Flinders University, Adelaide, South Australia, Australia

\section{Twitter Belinda Townsend @BelTownsend and Fran Baum @baumfran}

Contributors BT: contributed to study design, lead data collection and analysis, wrote first draft and revised in response to coauthor feedback. SF: conceived and devised study design, oversaw data collection and analysis, commented on paper drafts. TF: contributed to study design, lead data collection and analysis of NTER case, commented on paper drafts. AS: contributed to study design, data collection and analysis of trade case, commented on paper drafts. LS: contributed to study design, data collection and analysis of PPL case, commented on paper drafts. RL: contributed to study design, analysis of trade case, commented on paper drafts. TM: contributed to study design, data collection and analysis of NTER case, commented on paper drafts. FB: conceived and devised study design, oversaw data collection and analysis, commented on paper drafts.

Funding This work was funded by the Australian National Health and Medical Research Council (APP1078046). The NHMRC had no role in the conduct of this research.

Competing interests None declared.

Patient consent for publication Not required.

Ethics approval Ethics approval for this study was received from Flinders University Social and Behavioural Research Ethics Committee (Project number 6786) and The Australia National University Human Research Ethics Committee (Protocol 2015/243). All informants gave informed consent.

Provenance and peer review Not commissioned; externally peer reviewed.

Data availability statement All data relevant to the study are included in the article or uploaded as supplementary information.

Supplemental material This content has been supplied by the author(s). It has not been vetted by BMJ Publishing Group Limited (BMJ) and may not have been peer-reviewed. Any opinions or recommendations discussed are solely those of the author(s) and are not endorsed by BMJ. BMJ disclaims all liability and responsibility arising from any reliance placed on the content. Where the content includes any translated material, BMJ does not warrant the accuracy and reliability of the translations (including but not limited to local regulations, clinical guidelines, terminology, drug names and drug dosages), and is not responsible for any error and/or omissions arising from translation and adaptation or otherwise.

Open access This is an open access article distributed in accordance with the Creative Commons Attribution Non Commercial (CC BY-NC 4.0) license, which permits others to distribute, remix, adapt, build upon this work non-commercially, and license their derivative works on different terms, provided the original work is properly cited, appropriate credit is given, any changes made indicated, and the use is non-commercial. See: http://creativecommons.org/licenses/by-nc/4.0/.

ORCID iD

Belinda Townsend http://orcid.org/0000-0002-2480-2820

\section{REFERENCES}

1 Commission on the Social Determinants of Health. Closing the gap in a generation: health equity through action on the social determinants of health. Geneva: World Health Organization, 2008.

2 Word Heath Organization. Adelaide statement on health in all policies: moving towards a shared governance for health and wellbeing. Adelaide: government of South Australia and word Heath organization, 2010.

3 World Health Organization. Rio political Declaration on social determinants of health. Rio de Janeiro Brazil: world conference on social determinants of health and world Health organization, 2011.

4 The 8th global conference on health promotion. Helsinki, Finland: 10-14 Jun 2013. Available: http://www.who.int/healthpromotion/ conferences/8gchp/background/en/ [Accessed 6 Mar 2020].

5 Marmot M. Social determinants of health: a call for papers. The Lancet 1812;2008:371.

6 Marmot M, Allen J, Bell R, et al. Who European review of social determinants of health and the health divide. The Lancet 2012;380:1011-29.

7 Ottersen OP, Dasgupta J, Blouin C, et al. The Lancet-University of Oslo Commission on global governance for health. The political origins of health inequity: prospects for change. The Lancet 2014;383:630-67.

8 Marmot M. Social determinants of health inequalities. The Lancet 2005;365:1099-104.

9 Marmot M, Allen JJ. Social determinants of health equity. Am J Public Health 2014;104 Suppl 4:S517-9.

10 Penman-Aguilar A, Talih M, Huang D, et al. Measurement of health disparities, health inequities, and social determinants of health to support the advancement of health equity. J Public Health Manag Pract 2016;22 Suppl 1:S33-42.

11 Marmot M. Health equity in England: the Marmot review 10 years on. BMJ 2020;368:m693.

12 Murtin Fet al. Inequalities in longevity by education in OECD countries: insights from new OECD estimates. Paris: OECD Statistics Working Papers OECD Publishing, 2017. 
13 Deaths in Australia. Australian Institute of health and welfare. Canberra, Australia, 2019. https://www.aihw.gov.au/reports/lifeexpectancy-death/deaths-in-australia/contents/life-expectancy

14 Barten F, Mitlin D, Mulholland C, et al. Integrated approaches to address the social determinants of health for reducing health inequity. J Urban Health 2007;84:164-73.

15 Baum FE, Bégin M, Houweling TAJ, et al. Changes not for the fainthearted: reorienting health care systems toward health equity through action on the social determinants of health. Am J Public Health 2009;99:1967-74.

16 de Leeuw E, Clavier C, Breton E. Health policy - why research it and how: health political science. Health Res Policy Syst 2014;12:55.

17 Public Health Agency of Canada and World Health Organization. Health equity through intersectoral action: an analysis of 18 country case studies. Ottawa: Public Health Agency of Canada and World Health Organization, 2008. www.who.int/social_determinants/ resources/health_equity_isa_2008_en.pdf. (accessed 7 March 2020).

18 Braveman P, Gruskin S. Defining equity in health. J Epidemiol Community Health 2003;57:254-8.

19 Baum F, Fisher M. Why behavioural health promotion endures despite its failure to reduce health inequities. Sociol Health IIIn 2014;36:213-25.

20 Baker P, Friel S, Kay A, et al. What enables and constrains the inclusion of the social determinants of health inequities in government policy agendas? A narrative review. Int $J$ Health Policy Manag 2018;7:101-11.

21 Embrett MG, Randall GE. Social determinants of health and health equity policy research: exploring the use, misuse, and nonuse of policy analysis theory. Soc Sci Med 2014;108:147-55.

22 Klugman B. Effective social justice advocacy: a theory-of-change framework for assessing progress. Reprod Health Matters 2011;19:146-62.

23 Browne J, de Leeuw E, Gleeson D, et al. A network approach to policy framing: a case study of the National Aboriginal and Torres Strait Islander health plan. Soc Sci Med 2017;172:10-18.

24 Smith KE. Understanding responses to the political context of health inequalities in research and policy: can post-structural theories of power help? Soc Theory Health 2015;13:355-76.

25 Exworthy M, Blane D, Marmot M. Tackling health inequalities in the United Kingdom: the progress and pitfalls of policy. Health Serv Res 2003;38:1905-22.

26 Vallgårda S. Social inequality in health: dichotomy or gradient? A comparative study of problematizations in national public health programmes. Health Policy 2008;85:71-82.

27 Gamble VN, Stone D. U.S. policy on health inequities: the interplay of politics and research. J Health Polit Policy Law 2006;31:93-126.

28 Vallgårda S. Health inequalities: political problematizations in Denmark and Sweden. Crit Public Health 2007;17:45-56.

29 Dahl E, Lie M. Policies to tackle health inequalities in Norway: from laggard to pioneer? Int J Health Serv 2009;39:509-23.
30 Came H. Sites of institutional racism in public health policy making in New Zealand. Soc Sci Med 2014;106:214-20.

31 Smith KE. The politics of ideas: the complex interplay of health inequalities research and policy. Science and Public Policy 2014;41:561-74.

32 Hall PA, Taylor RCR. Political science and the three new institutionalisms. Polit Stud 1996;44:936-57.

33 Shiffman J, Smith S. Generation of political priority for global health initiatives: a framework and case study of maternal mortality. The Lancet 2007;370:1370-9.

34 Rushton S, Williams OD. Frames, paradigms and power: global health policy-making under Neoliberalism. Global Society 2012;26:147-67.

35 Australian Government. Australia's Paid Parental Leave Scheme: Supporting Working Families. Commonwealth of Australia, 2009.

36 Labonté R, Schram A, Ruckert A. The Trans-Pacific Partnership agreement and health: few gains, some losses, many risks. Global Health 2016;12:25.

37 Pomey M-P, Morgan S, Church J, et al. Do provincial drug benefit initiatives create an effective policy lab? the evidence from Canada. $J$ Health Polit Policy Law 2010;35:705-42.

38 Shearer JC, Abelson J, Kouyaté B, et al. Why do policies change? institutions, interests, ideas and networks in three cases of policy reform. Health Policy Plan 2016;31:1200-11.

39 Creswell JW. Qualitative inquiry and research design: Choosing among five approaches. 2nd edn. Thousand Oaks, CA: Sage, 2007.

40 Springer S, Birch K, MacLeavy J. The handbook of neoliberalism. Oxford: Routledge, 2016: 2

41 Townsend B, Friel S, Baker P, et al. How can multiple frames enable action on social determinants? Lessons from Australia's paid parental leave. Health Promot Int 2019.

42 Townsend B, Schram A, Labonté R, et al. How do actors with asymmetrical power assert authority in policy agenda-setting? A study of authority claims by health actors in trade policy. Soc Sci Med 2019;236:112430.

43 Elomäki A, Kantola J. Theorizing feminist struggles in the triangle of Neoliberalism, conservatism, and nationalism. Soc Polit 2018;25:337-60.

44 Townsend B, Friel S, Schram A, et al. What generates attention to health in trade PolicyMaking? lessons from success in tobacco control and access to medicines: a qualitative study of Australia and the (comprehensive and progressive) Trans-Pacific partnership. Int $J$ Health Policy Manag 2020. doi:10.34172/ijhpm.2020.80. [Epub ahead of print: 07 Jun 2020].

45 Alter KJ, Meunier S. The politics of international regime complexity. Perspectives on Politics 2009;7:13-24.

46 Castles F. The Working Class and Welfare: Welfare in Australia and New Zealand. Wellington: Allen and Unwin, 1985.

47 Hirono K, Haigh F, Gleeson D, et al. Is health impact assessment useful in the context of trade negotiations? A case study of the trans Pacific partnership agreement. BMJ Open 2016;6:e010339. 